\title{
Recordando o rei David: vivência coral e criatividade musical na Europa pós-carolíngia
}

Manuel Pedro Ferreira

\section{(2) OpenEdition}

\section{Journals}

\section{Edição electrónica}

URL: http://journals.openedition.org/medievalista/472

DOI: 10.4000/medievalista.472

ISSN: 1646-740X

\section{Editora}

Instituto de Estudos Medievais - FCSH-UNL

\section{Refêrencia eletrónica}

Manuel Pedro Ferreira, « Recordando o rei David: vivência coral e criatividade musical na Europa pós carolíngia », Medievalista [Online], 8 | 2010, posto online no dia 01 dezembro 2010, consultado no dia 19 abril 2019. URL : http://journals.openedition.org/medievalista/472 ; DOI : 10.4000/ medievalista.472 
Titulo: Recordando o rei David: vivência coral e criatividade musical na Europa pós-carolíngia.

Autor(es): Manuel Pedro Ferreira

Enquadramento Institucional: CESEM/ Faculdade de Ciências Sociais e Humanas da UNL Contacto: mpferreira@ fcsh.unl.pt

Fonte: Medievalista [Em linha]. №8, (Julho 2010). Direc. José Mattoso. Lisboa: IEM.

Disponível em: http://www2.fcsh.unl.pt/iem/medievalista/

ISSN: 1646-740X

\section{Resumo}

Este trabalho explora a presença do Rei David no quotidiano e no imaginário do clero latino medieval, através do Livro dos Salmos e de novas peças musicais (antífonas, sequências e tropos) inspiradas em episódios biográficos recolhidos no Antigo Testamento. Centrado em repertório consolidado por volta do século XI (com referências adicionais quer à mentalidade pré-carolíngia, quer ao impacto humanístico na polifonia do século XVI), põe em relevo a tensão entre uma estética musical expansiva e emotiva, associada a Cluny e à tradição ibero-aquitana, e o puritanismo patrístico reavivado, no século XII, pela Ordem de Cister. Entre os textos aqui apresentados pela primeira vez em português, contam-se passagens especialmente informativas, escritas em meados do mesmo século por João de Salisbúria, Hugo de Fouilloy e Elredo de Rieval.

\section{Abstract}

This paper explores the presence of King David in the daily life and imaginary world of Latin medieval clergy, focusing on the Psaltery and those musical items (antiphons, sequences, tropes) newly inspired in David's biography as recorded in the Old Testament. Although referring both to pre-Carolingian mentality and to 16th-century 
humanism as mirrored in contemporary polyphony, it takes as its main object the liturgical repertory in existence around the 11th century. In so doing, it puts into evidence the tension between an expansive, emotional musical aesthetics (mainly associated to Cluny and the Aquitanian and Aquitanian-derived traditions) and the patristic puritanism revived by the Cistercians in the 12th century. Among those texts translated here into Portuguese for the first time, passages from 12th-century authors John of Salisbury, Hugh of Fouilloy and Aelred of Rievaulx are particularly telling.

\title{
Recordando o rei David: vivência coral e criatividade musical na Europa pós-carolíngia
}

\author{
Manuel Pedro Ferreira
}

Este texto, que serviu de base a uma palestra havida na FCSH a 7 de Maio de 2010, é a versão ampliada de uma comunicação apresentada ao V Encontro Cultural de São Cristóvão de Lafões a 8 de Maio de 2009.

Pouco depois do ano mil antes de Cristo, o chefe de um exército de mercenários, entretanto aclamado senhor da Judeia, chamado David, tornou-se rei de Israel, destronando a linhagem de Saul, morto em batalha contra os filisteus. Jerusalém tornou-se a capital e o centro religioso de uma entidade política de organização algo difusa cujo território, poderio e influência regional David logrou aumentar consideravelmente, através da guerra e da diplomacia, durante mais de trinta anos ${ }^{1}$. A afirmação política do reino passou também pela legitimação interna e externa da Casa de David, conseguida graças à unificação religiosa e a várias contribuições narrativas e poéticas, que, refundidas e expandidas através dos séculos, confluíram na Bíblia.

\footnotetext{
${ }^{1}$ André LEMAIRE, «The United Monarchy: Saul, David and Solomon», in Hershel Shanks (ed.), Ancient Israel: From Abraham to the Roman Destruction of the Temple, revised and expanded edition, Washington: Prentice Hall/Biblical Archaeology Society, 1999, pp. 91-120.
} 
No primeiro Livro de Reis, igualmente dito de Samuel (I Sam. 16:17-23), narra-se como a sua arte de citarista conquistou o coração e aliviou o espírito do rei Saul. Quando a Arca da Aliança foi transportada para Jerusalém, David, já na sua qualidade de rei de Israel, e todos os que o acompanhavam, dançaram e tocaram, diante do Senhor, liras, saltérios, tambores, matracas, címbalos e chincalhos (II Sam. 6:5) ${ }^{2}$.

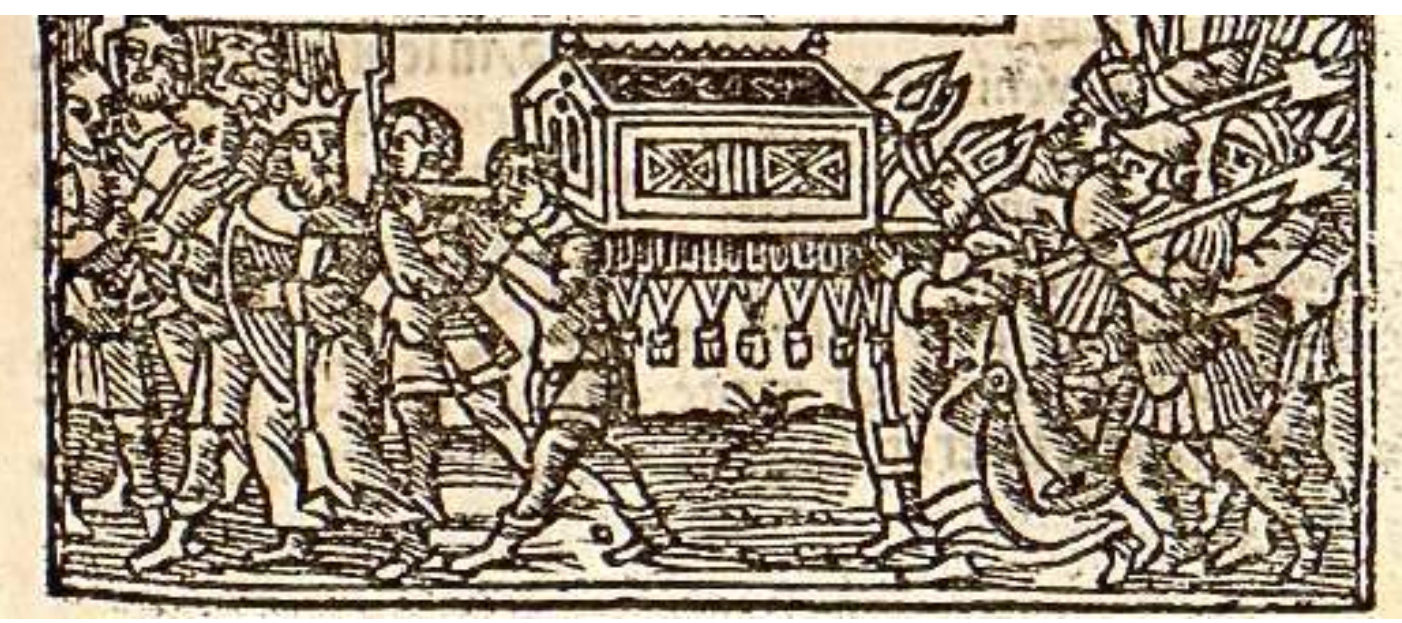

Ex. 1 - O Rei David com a sua harpa, entrando em Jerusalém com a Arca da Aliança (gravura do Breviário de Santa Cruz impresso em 1531)

Atribui-se por conseguinte a David, nas religiões de raiz bíblica, uma invulgar competência de instrumentista, com proverbiais poderes curativos. Uma antiga tradição judaica, reavivada em época carolíngia, apresenta-o igualmente como inventor de instrumentos musicais (o que concorda com o Salmo 150, segundo o qual se deve louvar a Deus com todo o tipo de instrumentos) $)^{3}$.

De maiores consequências é ter-lhe sido atribuída a composição de muitos, ou até de todos os cento e cinquenta Salmos bíblicos. De facto, no tempo de Jesus estava já instalada a convicção, depois transmitida pelo Novo Testamento e pelos autores patrísticos, de que o Saltério era inteiramente obra sua, convicção que se prolongou por toda a Idade Média — as rubricas que precedem cada salmo mencionam o nome de David em quase metade dos casos, sobretudo até ao Salmo 70 (71), embora nem sempre se trate de atribuições, e muitos outros

\footnotetext{
2 Joachim BRAUN, Music in Ancient Israel/Palestine: Archeological, Written, and Comparative Sources, Grand Rapids (Michigan): Eerdmans, 2002, p. 107. A lista de instrumentos na passagem correspondente nas Crónicas (I Par. 13:8) é diferente, revelando uma filtragem tardia tendente a eliminar associações com práticas orgiásticas pagãs.

${ }^{3}$ Esta tradição radica no Salmo 151 (apócrifo), que é uma autobiografia fictícia de David, na qual ele aparece a construir uma lira e um instrumento de sopro: cf. Samuel TERRIEN, The Psalms. Strophic Structure and Theological Commentary, Grand Rapids (Michigan): W. B. Eerdmans, 2003, p. 931; Joachim BRAUn, op. cit., p. 32; Martin VAN SCHAIK, The Harp in the Middle Ages: The Symbolism of a Musical Instrument, Amsterdam: Rodopi, 1992, pp. 45-46.
} 
nomes sejam referidos ${ }^{4}$. Daí que o livro dos Salmos, que é na verdade uma antologia, tardiamente estabilizada, com diversas camadas e origens, muitas vezes se apresente nas fontes antigas, manuscritas ou impressas, com uma especial marca de autor: uma iluminura ou gravura inicial, na qual se representa David tocando um instrumento ${ }^{5}$.

Este é frequentemente um saltério ou uma harpa; mais raramente, o rei surge a tocar um pequeno carrilhão, uma viola de arco ou uma lira. Do ponto de vista histórico, a lira é o instrumento que mais plausivelmente lhe pode ser associado (como sucede na ilustração seguinte, retirada de uma Bíblia do século XII, proveniente de Worms) ${ }^{6}$.

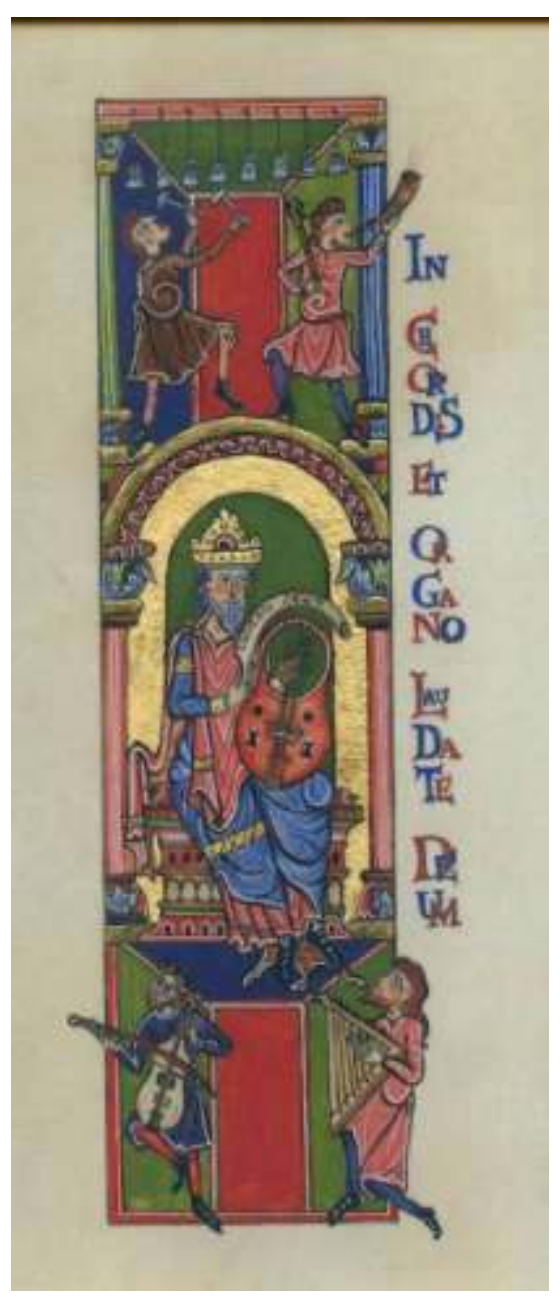

Ex. 2 - Vê-se aqui o Rei David tocando a lira, rodeado de músicos; observe-se também a citação do Salmo 150: «Laudate Deum [...] in chordis et organo»

\footnotetext{
${ }^{4}$ Cf. Samuel TerRIEN, op. cit.

${ }^{5}$ Sobre a tradição iconográfica do rei David enquanto harpista, veja-se Martin VAN SCHAIK, op. cit.

${ }^{6}$ Cf. Joachim BRAUN, op. cit., pp. 17-18. Sobre a lira medieval, veja-se Catherine HOMO-LECHNER, Sons et instruments de musique au Moyen Age. Archéologie musicale dans l'Europe du VIIe au XIVe siècles, Paris: Errance, 1996, pp. 87-89. A imagem seleccionada está disponível no sítio [www.enluminuremedievale.com/]. Podem encontrar-se muitos outros exemplos de iluminuras representando o Rei David, em manuscritos conservados nas bibliotecas públicas francesas, no sítio [www.enluminures.culture.fr/].
} 
Enquanto Moisés selara com Deus uma Aliança passível de ser invalidada, o salmo 88 (89) apresenta a linhagem e o trono de David como divinamente estabelecidos até ao final dos tempos, e o salmo 109 (110) sacraliza essa nova e indestrutível Aliança. A ideologia messiânica que parte da profecia de Natan (II Sam. 7) e se actualiza no «livro do Emanuel» do Proto-Isaías (7: 13-15; 9: 6-7; 11:1-5) supõe a continuidade, através de tempos históricos conturbados, da Aliança com a Casa de David ${ }^{7}$.

Os cristãos reivindicaram para Jesus, reconhecido como Messias, a linhagem e o trono prometido aos descendentes de David, o que torna a sua figura central na justificação da fé e confere um cunho profético à produção poética que lhe é atribuída. Os seus cânticos passaram então a ser interpretados em clave cristológica, incluindo não só o Advento, mas também a Paixão e a Ressurreição de Jesus, que numa passagem dos Evangelhos explica que «era necessário que se cumprisse tudo o que de Mim estava escrito na Lei de Moisés, e nos Profetas, e nos Salmos» (Luc. 24:44). Os Salmos não só constituíram o repertório musical do Templo de Jerusalém até à sua destruição no ano 70 d.C., como vieram a constituir o mais importante núcleo textual do repertório litúrgico cristão, indissociável da exegese teológica desenvolvida no seio da Igreja primitiva.

A interpretação do Saltério em clave cristológica extravasou mesmo para a literatura em língua vernácula, como no seguinte excerto do Libro de buen amor de Juan Ruiz, escrito no século XIV (estrofe 1061, por mim traduzida): a Paixão de Jesus aparece aí profetizada por Daniel e prefigurada nos Salmos de David.

Os que a lei havemos/ de Cristo a guardar sua morte devemos/ chorar e recordar.

$[\ldots]$

Diz outra profecia

daquela velha Lei [o Antigo Testamento]

que o Anho morreria [cordeiro sacrificado: Agnus Dei]

e salvaria a grei:

Daniel o dizia

por Cristo nosso rei; [tendo em mente Cristo]

e em David o lemos, [ [David = seus Salmos]

segundo o meu julgar.

\footnotetext{
${ }^{7}$ Joaquim Carreira das NeVES, O que é a Bíblia, Alfragide: Casa das Letras, 2008, pp. 180-206.
} 
A par da centralidade do seu simbolismo religioso, David foi igualmente reconhecido como uma figura histórica ímpar, já que na Idade Média - época em que a memória secular mais recente, inicialmente veiculada por cantares de gesta, apenas despontava como literatura — as narrativas bíblicas formavam o grosso do horizonte histórico credível, internacionalmente partilhado e acessível à leitura. Não importa que essas narrativas tivessem sido, no seu tempo, criadas, filtradas ou recompostas de modo a promover pontos de vista particulares, e que a crítica moderna tenha posto a nu a sua relatividade; elas eram repetidamente lidas, recordadas e comentadas (frequentemente de forma alegórica) como parte do culto divino, e as peças musicais que enquadravam este culto foram incessantemente alimentadas, não só pelos Salmos de David, como pela factualidade bíblica ligada ao seu nome. Neste trabalho, procurarei balizar e dar alguns exemplos de reminiscências davídicas quer na prática e criação musical da Igreja latina durante a Idade Média, quer na discussão que essa prática e criação suscitaram em época pós-carolíngia. Focarei especialmente a época de formação das liturgias latinas e os séculos XI e XII, embora sem me coibir de recuar ou avançar na cronologia, se tal vier a propósito. Depois de falar da música enquanto forma de proclamação e de sinalização, tratarei de: Salmodia e contemplação; David na vivência do Saltério; David nas antífonas do Ofício; David nos tropos e sequências da Missa; e David no debate estético do século XII. Dispenso-me de tratar outros aspectos, como os responsórios alusivos a David, ou a sua comemoração litúrgica como santo e profeta nos dias 29 ou 30 de Dezembro, celebração esta que se circunscreve à área germânica ou circundante.

\section{Música como proclamação e sinalização}

Na liturgia cristã a música foi entendida, em primeiro lugar, como um modo eficaz de proclamação do texto sacro. A entoação musical não só tem o efeito de melhorar a projecção acústica, como lhe fornece um instrumento de controle, a unifica e a distingue do discurso verbal quotidiano. A cantilação do texto, com marcação de divisões e pontuações gramaticais, tornou-se, assim, um método universal de sacralização oral em contexto público e cerimonial. Embora houvesse, no século quarto, diversas práticas e diferentes opiniões sobre a latitude melódica e a variabilidade admissíveis no canto litúrgico - mais ou menos próximo da fala, mais ou menos expansível artisticamente - a proclamação do texto sacro tornou-se um fenómeno indissociável da formatação e da invenção musicais.

É sabido que a fé cristã se renova e revivifica através da comemoração ritual, ao longo do calendário, dos eventos centrais da vida de Jesus e dos seus seguidores; a ideia de divindade reteve, para além disso, no Cristianismo, a sua milenar associação simbólica à luz. Isto implicou 
a criação de ritmos litúrgicos à escala do ano (ciclos do Advento-Natal-Epifania e da QuaresmaPáscoa-Pentecostes), da semana (ciclo dominical) e do dia (ciclo solar). A música associada aos textos litúrgicos foi sendo progressivamente diferenciada de modo a servir como sinalização temporal (reservando certas sonoridades para o ofício nocturno, para os domingos e festas principais, para o primeiro dos dias feriais, ou para os períodos penitenciais do ciclo anual) ou como sinalização hierárquica (reservando-se uma maior elaboração melódica e uma execução mais solene para os rituais ou momentos mais importantes, como a Missa ou o Natal).

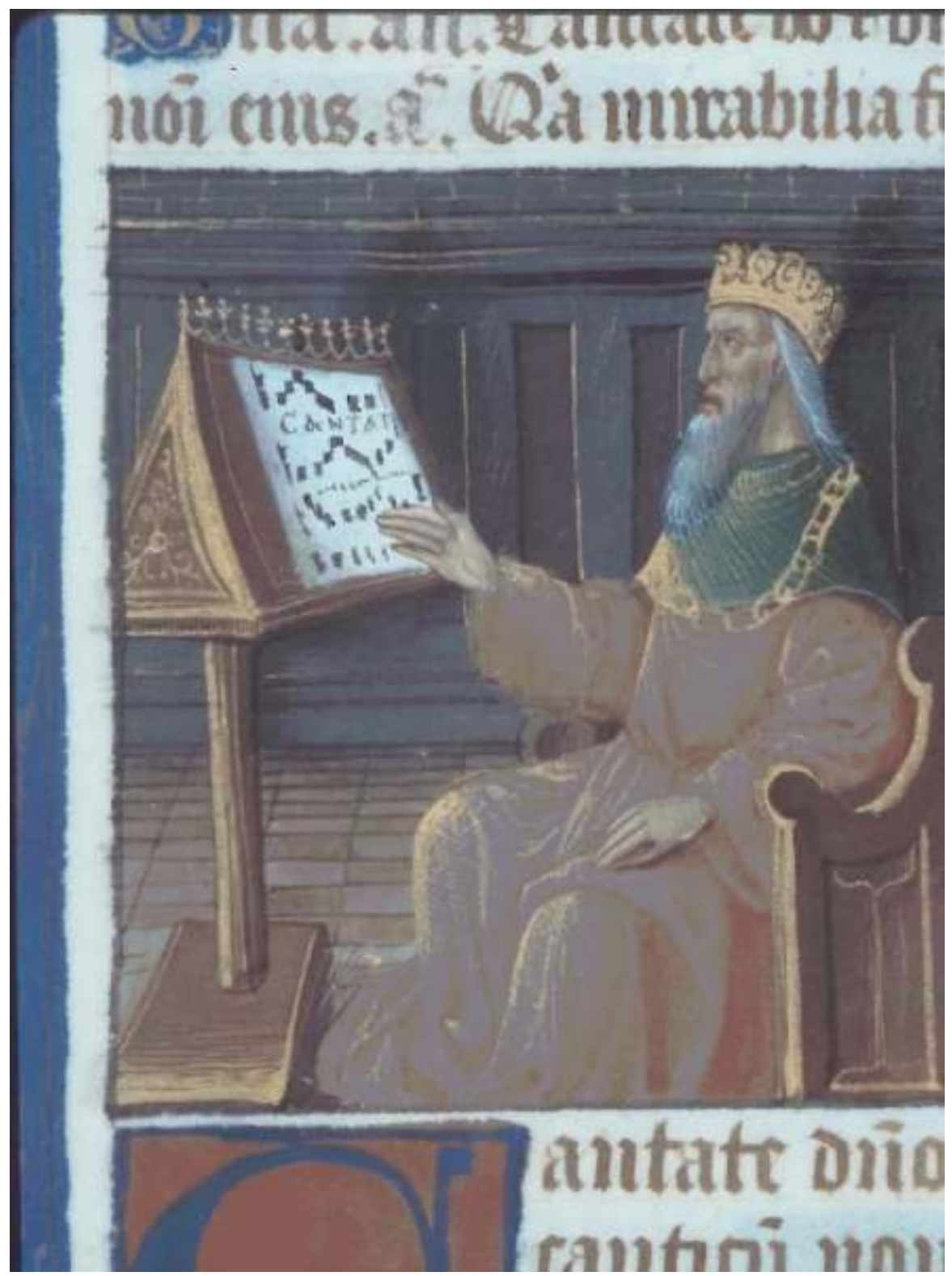

Ex. 3 - Nesta representação do Rei David num breviário de Moissac do século XV (New York, Pierpont Morgan Library, M 463, fol. 306), o início do Salmo 95 (96), Cantate Domino canticum novum, simboliza a continuidade entre o louvor davídico ao Senhor e a leitura coral quotidiana no âmbito do Ofício Divino. 


\section{Salmodia e contemplação}

A melodização do texto, ampliando e prolongando o seu som, tanto em projecção externa como em ressonância interna, serviu ainda para induzir a imersão e a ruminação meditativas, função esta que foi decisivamente impulsionada pelo movimento monástico, o qual deixou marcas indeléveis na liturgia das catedrais, ao mesmo tempo que se adaptou aos seus ritmos urbanos. A salmodia contínua, típica dos primeiros tempos de monaquismo, foi regulada de modo a integrar as horas de Laudes e de Vésperas, populares nas cidades, e a tirar partido das vigílias nocturnas que, em certas ocasiões litúrgicas, aí se tinham estabelecido com larga participação dos fiéis. Os salmos foram, na sua totalidade, ou contemplados nessas horas do Ofício divino, ou distribuídos por «horas menores» (Prima, Tércia, Sexta, Noa e Completas).

A liturgia romana, no que respeita ao Ofício divino, é, de facto, na sua génese, a liturgia das comunidades monásticas ao serviço das igrejas de Roma. A posterior distinção entre «percursos» secular e monástico, através da qual se cristalizaram costumes litúrgicos diferenciados - consoante as influências, as preferências e os contextos de inserção mundana ou de contínuo retiro espiritual dos respectivos grupos clericais - fez-se com base num horizonte já profundamente influenciado pela rotina dos mosteiros urbanos.

É sabido que na Igreja latina (salvo excepções, como no rito ambrosiano) o clero devia salmodiar, ao longo da semana, todos os cento e cinquenta salmos, segundo uma distribuição e uma ordem pré-estabelecidas, repetindo-se alguns deles ou todos os dias, ou nos dias feriais, ou de $3^{\text {a }}$-feira em diante ${ }^{8}$. Nas Laudes, por exemplo, segundo a regra beneditina, os salmos 50 e 66 eram repetidos diariamente. Já segundo o costume de Roma, na maior parte dos domingos, o salmo 50 dava lugar ao 92; observava-se, adicionalmente, a repetição diária do salmo 62, cantado antes do 66. Os cânticos vetero-testamentários e evangélicos incorporados no Ofício eram assimilados, na sua execução, ao estilo salmódico. As peças de canto que enquadravam a salmodia eram, por sua vez, quase sempre baseadas em versículos de Salmos.

Convém lembrar que a celebração das horas do Ofício era uma actividade colectiva, efectuada num espaço especialmente destinado na igreja a esse fim: o coro. A presença e participação dos clérigos no coro era uma obrigação exigente, fisicamente esgotante e mentalmente propícia à divagação. Havia que estar atento simultaneamente à postura corporal e à postura mental, de modo a contrariar a dissociação entre o canto e a actividade racional.

\footnotetext{
${ }^{8}$ Pierre-Marie Gy, «La Bible dans la liturgie au Moyen Age», in Pierre Riché \& Guy Lobrichon (eds.), Le Moyen Age et la Bible, Paris: Beauchesne, 1984, pp. 537-52.
} 
Desenvolveram-se, pois, em torno dos salmos cantados no coro, várias estratégias visando a concentração contemplativa. Criaram-se títulos, de maior ou menor extensão, para cada salmo, explicitando a respectiva interpretação cristológica; fizeram-se resumos dos mesmos, tendo em conta os correspondentes comentários patrísticos; ensaiaram-se glosas várias em torno do sentido de cada frase; associaram-se os salmos à meditação sobre cada parte do corpo de Cristo; ou sobre os seus mistérios; ou sobre a sua humanidade; ou sobre os factos da sua Paixão.

As comunidades mais rigoristas, como a Ordem cisterciense, privilegiavam uma dicção grave e pausada dos textos, com longos intervalos entre versículos, de modo a que pudesse aí grassar a reflexão contemplativa, ou ser dita uma oração. O tempo assim dispendido, mormente nas longas horas nocturnas, era frequentemente visto como uma provação, valorizada, na linha do monaquismo primitivo, enquanto mortificação colectiva. É talvez significativo que nessas circunstâncias a disciplina coral chegasse a ser comparada a uma crucificação: a uma união, de corpo e alma, de cada coralista com o Cristo sofredor'.

\section{David na vivência do Saltério}

Se o Ofício divino, na sua modalidade clássica, surge da regulação horária de uma salmodia contínua, também nas composições musicais da Missa os textos eram maioritariamente retirados dos Salmos, embora se fizesse largo uso de outros livros do Antigo Testamento $^{10}$. O canto da Igreja colocou-se assim, em sentido lato, sob a égide de David.

Também não faltavam ocasiões para o reencontrar espiritualmente de forma mais directa. Todos os dias, ou quase, na hora de Laudes, cada coralista cantava o Miserere (Ps. 50), sendo convidado a ruminar sobre as suas palavras. Nesta ruminação, David aparecia simultaneamente como voz da Igreja e como protagonista histórico.

\footnotetext{
${ }^{9}$ Edmund MiKkers, «Un traité inédit d'Étienne de Salley sur la psalmodie», Cîteaux - Commentarii cistercienses, $\mathrm{n}^{\circ}$ (1972), pp. 245-88. Thomas MERTON, «St. Aelred of Rievaulx and the Cistercians (IV)», Cistercian Studies, vol. 23 (1988), pp. 45-62.

${ }^{10}$ Dominique M. FOURNIER, «Sources scripturaires et provenance liturgique des pièces de chant du Graduel de Paul VI», Études grégoriennes, vol. 21 (1986), pp. 97-114.
} 


\begin{tabular}{|c|c|}
\hline $\begin{array}{l}\text { Magistro choro. Psalmus. David, } \\
\text { cum venit ad eum Nathan propheta, } \\
\text { postquam cum Bethsabee peccavit. }\end{array}$ & $\begin{array}{l}\text { Do mestre de canto. Salmo. De David. } \\
\text { Quando o profeta Natan foi ter com ele, } \\
\text { depois de ter pecado com Betsabé. }\end{array}$ \\
\hline $\begin{array}{l}\text { Miserere mei, Deus, secundum } \\
\text { misericordiam tuam, et secundum } \\
\text { multitudinem miserationum tuarum, } \\
\text { dele iniquitatem meam. }\end{array}$ & $\begin{array}{l}\text { Tem piedade de mim, ó Deus, } \\
\text { pelo Teu amor, e pela } \\
\text { Tua grande compaixão, } \\
\text { apaga a minha culpa! }\end{array}$ \\
\hline $\begin{array}{l}\text { Amplius lava me ab iniquitate mea } \\
\text { et a peccato meo munda me; }\end{array}$ & $\begin{array}{l}\text { Lava-me da minha injustiça } \\
\text { e purifica-me do meu pecado! }\end{array}$ \\
\hline $\begin{array}{l}\text { Quoniam iniquitatem meam } \\
\text { ego cognosco, et peccatum meum } \\
\text { contra me est semper. }\end{array}$ & $\begin{array}{l}\text { Porque eu reconheço a minha culpa, } \\
\text { e o meu pecado está sempre } \\
\text { diante de mim. }\end{array}$ \\
\hline $\begin{array}{l}\text { Tibi, tibi soli peccavi } \\
\text { et malum coram te feci, } \\
\text { ut iustus inveniaris in sententia tua } \\
\text { et aequus in iudicio tuo. }\end{array}$ & $\begin{array}{l}\text { Pequei contra Ti, somente contra Ti, } \\
\text { praticando o que é mau aos Teus } \\
\text { olhos, para que se manifeste, ao falares, } \\
\text { Tua justiça, e no juízo, Tua rectidão. }\end{array}$ \\
\hline
\end{tabular}

Ex. 4 - O início do Salmo 50 (ou 51), segundo a Vulgata latina, com a respectiva tradução portuguesa

A antiga tradição interpretativa do Salmo 50 (51) apresentava-o como um canto de penitência ou como um modelo de confissão; mas punha-o também na boca de David, como lamento expiatório por actos traiçoeiros (II Sam. 11 - adultério com Betsabé e homicídio de Urias, seu marido), expiação essa motivada, segundo a Vulgata latina, pela admoestação do profeta Natan (II Sam. 12). No seu comentário ao Miserere, Santo Agostinho é explícito:

«A queda de um homem tão forte como David deve fazer-nos medir a nossa fraqueza, para não desejarmos o que Deus nos proíbe. De longe viu David a mulher, mas o desejo estava perto. O que ele via estava longe, o que o perdeu estava nele [...] Talvez me respondas: "Eu resisto com força!" Serás tu mais forte que David? Dissemos o que se deve evitar; escutemos agora o que se deve imitar, se alguém vier a cair. Há muitos que 
querem cair com David, mas não querem levantar-se como David. Não foi para cair que a sua queda nos foi dada como exemplo, mas para que, se caíres, te levantes. Tem cuidado para não caíres. A queda dos grandes não deve fazer a alegria dos pequenos, mas inspirar-lhes temor. É o fim desta história: para isso foi escrita, para isso a Igreja lê e canta muitas vezes este salmo $[\ldots]{ }^{11}$.

A presença viva de David na reflexão contemplativa em torno do saltério variava, de resto, segundo as correntes e modelos exegéticos ou segundo as capacidades e preferências da imaginação. Pelo Ocidente circulavam, por exemplo, algumas listagens exaustivas de «títulos explicativos» para os Salmos, elaboradas entre c. 300 e o final do século VI, mas frequentemente recopiadas até ao século XII. São elas: a série de S. Columba, divulgada a partir da Irlanda; a de S. Agostinho de Cantuária, também de origem insular mas conhecida na Ibéria; uma outra, inspirada em S. Jerónimo, preferida na tradição visigótica; uma série de origem grega, conhecida na Ibéria e em Monte-Cassino, traduzida de Eusébio de Cesareia; outra inspirada em Orígenes, de origem presumivelmente gaulesa; e finalmente, a série de Cassiodoro, resumida por Beda, que ganhou raízes em Milão ${ }^{12}$. Nestas listagens reina a interpretação simbólico-alegórica, segundo a qual os Salmos devem ser lidos como prefigurando os eventos do Novo Testamento e o posicionamento espiritual da Igreja ${ }^{13}$. É notável que só a série de origem grega dê ao David histórico um lugar de destaque, aproveitando, de resto, a sua menção nas rubricas dos salmos, mas juntando-lhe uma dimensão profética cristã:

Salmo 3: Profecia a David, sobre os males que sobre ele se irão abater;

Salmo 4: Profecia a David, sobre o que lhe sucederá de bem;

Salmo 7: Confissão de fé de David e profecia sobre os gentios;

Salmo 17: Acção de graças de David e profecia do Advento e Ascensão de Cristo;

Salmo 20: Súplica dos que avançam em união com David;

Salmo 56: Acção de graças de David e profecia da vocação dos gentios;

Salmo 85: Súplica de David e profecia da vocação dos gentios;

Salmo 131: Oração de David e manifestação luminosa de Cristo [Epifania];

Salmo 137: Acção de graças e profecia de David.

11 Santo Agostinho, Enarrationes in psalmos, trad. de José de Leão Cordeiro in Saltério litúrgico. Salmos e cânticos da liturgia das horas com introduções, comentário patrístico e orações conclusivas, $3^{\mathrm{a}}$ ed., Coimbra: Secretariado Nacional de Liturgia, 1999, p. 204.

${ }^{12}$ Pierre SALMON, Les «Tituli psalmorum» des manuscrits latins, Paris: Les Éditions du Cerf, 1959.

13 Sobre a importância da abordagem simbólico-alegórica na mentalidade medieval, veja-se Umberto ECO, Arte e Beleza na Estética Medieval, Lisboa: Presença, 1989. 
Comparativamente, as outras séries secundarizam o contexto vetero-testamentário, preferindo ouvir nos Salmos, sem mediação personalizada, a voz da Igreja, a voz de Cristo, a voz do Espírito Santo... as excepções abarcam somente três composições, nas quais não surpreende a presença do Salmo 143, já que incorpora num versículo o nome do rei de Israel:

Salmo 17 (série de S. Columba): Diz David, à semelhança de Cristo;

Salmo 131 (série de S. Agostinho de Cantuária): É a voz do Pai a David, testemunhando que porá um fruto do seu ventre sobre o seu trono;

Salmo 143 (série de Cassiodoro/Beda): Esta guerra de David prefigura a do Cristo Salvador, para que, assim como Golias foi por aquele derrubado em combate pelo arremesso de uma pedra, pela pedra que é a fortaleza de Cristo o diabo seja vencido.

O relativo apagamento do David histórico relaciona-se com o peso da interpretação alegórica da sua figura, tal como tinha sido praticada por Clemente de Alexandria e S. João Crisóstomo. O primeiro viu David como um ordenador, divinamente inspirado, quer do macrocosmo quer do microcosmo humano:

«Pelo poder do Espírito Santo, [David] dispôs harmoniosamente este grande mundo; e também o pequeno mundo, o do corpo e da alma. E faz música para Deus neste instrumento plurissonante do cosmos, e [assim] canta com o instrumento humano» ${ }^{14}$.

S. João Cristóstomo contrapôs à música profana a salmodia, na qual via idealmente corporizado o princípio de harmonização apaguizadora simbolizado pela lira de David:

«Aqueles que invocam David com a sua lira apelam intimamente a Cristo. Onde está Cristo, não há demónio que ouse entrar, nem sequer espreitar; mas a paz, e a caridade, e todas as coisas boas aí fluirão como se de fontes [...] Mesmo que o sentido das palavras te escape, ensina a tua boca a proferi-las, porque a língua é santificada pelas palavras, quando são ditas por uma mente zelosa e benevolente. Uma vez adquirido este hábito, não descuraremos um ofício tão belo, nem por vontade nem por descuido; o costume levar-nos-á, até contra o nosso querer, a levar a cabo diariamente este culto. Ninguém

\footnotetext{
${ }^{14}$ Passagem retirada de Protreptikos. Versão baseada na tradução inglesa do original grego apresentada por Martin van SCHAIK, op. cit., p. 41.
} 
será criticado, no canto, pela debilidade devida à muita juventude ou à idade avançada, ou pela voz tosca, ou pela total ausência de noções de ritmo. O que se pretende é espírito sóbrio, mente alerta, coração contrito, razão sólida e consciência clara; se com isso tiveres entrado no sagrado coro de Deus, poderás ficar ao lado do próprio David. Aqui não há necessidade de cítara, ou de cordas tendidas, ou de um plectro e de técnica, ou de qualquer instrumento musical; mas, se quiseres, podes tu próprio tornar-te uma cítara pela mortificação dos membros da carne, afinando corpo e alma em total harmonia» ${ }^{15}$.

Esta posição patrística encontrará eco na época pós-carolíngia, mas com uma inflexão subtil: onde antes se recomendava o automatismo do hábito, agora exige-se o predomínio da consciência; onde antes se falava de mortificação corporal, agora insiste-se na compunção espiritual. Deste modo, Amalário de Metz no seu Liber officialis prolonga a abordagem alegórica, defendendo que

«Os nossos cantores não têm nas suas mãos nem címbalos, nem liras, nem cítaras, nem qualquer outro tipo de instrumento, mas os seus corações [...] Os próprios cantores são a trompa, o saltério, o tambor, o coro, as cordas, o órgão e os címbalos».

Um outro autor do início do século IX, o monge Smaragdo de S. Mihiel, no seu comentário à Regra de São Bento, sublinha, por outro lado, que

«Aquele que canta com sabedoria, é o que compreende aquilo que canta; pois ninguém pode agir sabiamente se não compreende o que faz. Aquilo que em todas as comidas é o gosto, isso pelo qual um sabor é identificado, na palavra das santas Escrituras é o senso e a prudência. Se alguém, então, ocupar o seu espírito com as palavras singulares da salmodia do mesmo modo que o seu gosto se aferra ao sabor discreto da bebida, será ele a cumprir o que Psallite sapienter (Ps. 46) quer dizer. É bom orar sempre com o coração, do mesmo modo que é bom glorificar a Deus com o som da voz, cantando hinos espirituais. De nada vale cantar só com a voz, sem intenção do coração. Ou seja, deve cantar-se não só com a voz, mas com o coração» ${ }^{16}$.

\footnotetext{
${ }^{15}$ Passagem retirada da Exposição do Salmo 41. Versão baseada na tradução inglesa do original grego apresentada em Oliver STRUNK/Leo TREITLER, Source Readings in Music History, revised edition, New York: W. W. Norton, 1998, pp. 123-26.

${ }^{16}$ Textos citados por Gunilla IVERSEN, «Le son de la lyre des vertus. Sur la musique dans la poésie liturgique médiévale», in La place de la musique dans la culture médiévale, ed. Olivier Cullin, Turnhout: Brepols, 2007, pp. 47-69 [54-55].
} 


\section{David nas antífonas do Ofício}

Na prática musical latina, os salmos são cantados de forma antifonal, alternando as intervenções de cada lado do coro (ainda que representado por um solista) e enquadrados por uma antífona coral de execução conjunta, que primitivamente regressava entre versículos, servindo de refrão. Na Missa, as antífonas (de Intróito e Comunhão) foram ganhando protagonismo musical, reduzindo-se o número de versículos salmódicos até restarem um ou dois (no Intróito) ou desaparecerem de todo (na Comunhão, quando se restringiu a participação comunitária); no Ofício, os Salmos continuaram a ser cantados na íntegra (embora por vezes divididos em secções, distribuídas por vários momentos litúrgicos), enquanto o retorno da antífona inicial foi reduzido à apresentação final, após concluído o Salmo e proclamado o Gloria patri.

As antífonas do Ofício retiram os seus textos normalmente dos Salmos, e frequentemente do próprio Salmo que enquadram. No entanto, durante o Verão e o início do Outono, no período que se segue a Pentecostes, as leituras de Matinas são retiradas do Antigo Testamento, e muitas antífonas, mais de uma centena, foram compostas com base nessas leituras. Destas antífonas, cerca de dois terços são inspiradas nos livros históricos, com quase metade delas retiradas dos quatro livros de Reis (I-II Samuel, III-IV Reis). Das 35 antífonas de Regum listadas por Ruth Steiner, só 13 são de circulação corrente, podendo ser consideradas como formando a camada litúrgica mais antiga. As restantes, que aparecem em poucos manuscritos, correspondem certamente à expansão pós-carolíngia do repertório, desenvolvida regionalmente ou em contextos clericais particulares.

Quando, na primeira metade do século XII, a Ordem cisterciense fez a sua escolha de antífonas baseadas nos livros de Reis, optou por dez delas, todas pertencentes à camada litúrgica primitiva:

\begin{tabular}{|l|l|}
\hline Loquere domine quia audit (CAO 3636) & I Sam. 3:9 \\
Cognoverunt omnes (CAO 1849) & I Sam. 3:20 \\
Praevaluit David (CAO 4368) & I Sam. 17:50 \\
Iratus rex Saul (CAO 3411) & I Sam. 22:14 \\
Quis enim in omnibus (CAO 4546) & I Sam. 22:14 \\
Nonne iste est David (CAO 3948) & I Sam. 18:7 \\
\hline
\end{tabular}




\begin{tabular}{|l|l|}
\hline Doleo super te frater (CAO 2321) & II Sam. 1 \\
Rex autem David (CAO 4650) & II Sam. 18:33/19:4 \\
Obsecro domino aufer (CAO 4099) & II Sam. 24:17 \\
Unxerunt Salomonem (CAO 5280) & III Reg. 1:45 \\
\hline
\end{tabular}

Ex. 5: selecção cisterciense das antífonas de Regum

Como se vê na coluna direita deste quadro, os textos são quase sempre retirados dos dois primeiros livros de Reis, escolha que põe a história de David em especial evidência. Não obstante, em certos ambientes monásticos isto não era suficiente. A emoção do lamento de David pela morte de Saul e Jónatas (II Sam. 1) calou fundo no espírito da família cluniacense, a qual, em vez de uma só antífona baseada nesse texto, ou duas, como noutros costumes litúrgicos, preferiu ter quatro:

Montes Gelboe nec ros (CAO 3807)

Saul et Jonathas amabiles (CAO 4820)

Planxit autem David planctum (CAO 4298)

Doleo super te frater (CAO 2321)

Entre os monges beneditinos e o clero catedralício do sul de França, não só se adoptaram estas quatro antífonas, como foram ainda admitidas ou compostas algumas outras, que reforçam sobremaneira a presença de David na meditação coral sobre os livros de Reis:

\begin{tabular}{|c|c|}
\hline Et ait dominus ad Samuel & I Sam. 16:12 \\
\hline Laetatus est rex David (CAO 3566) & II Sam. 6:16 \\
\hline Incedens rex et sic & II Sam. 18:33 \\
\hline David sedens in cathedra & II Sam. 23:8 \\
\hline Appropinquaverunt autem dies & III Reg. 2:1-2 \\
\hline
\end{tabular}

Ex. 6: antífonas adicionais em fontes aquitanas

Podemos perguntar-nos quais seriam as razões por detrás desta escolha textual. As antífonas do Ofício serviam como meio de expressão afectiva ou ideológica de uma 
comunidade, revelando a sua sensibilidade espiritual ou as suas convicções religiosas. No caso vertente podemos identificar diversas motivações:

«Et ait dominus»: a valorização da unção do jovem David por Samuel, prefigurando o papel legitimador dos bispos, está na linha do movimento de reforma gregoriana que marcou a segunda metade do século XI; reforça a mensagem promovida pela antífona «Unxerunt Salomonem», mais disseminada.

«Laetatus est rex David»: celebra a entrada da arca do Senhor em Jerusalém, e assim sendo, glorifica o espaço da igreja enquanto herdeira do antigo Templo.

«Incedens rex et sic»: ao insistir no lamento de David pelo filho Absalão, já presente em «Rex autem», denuncia o gosto pela intensificação emocional na contemplação coral, já detectada na família cluniacense em torno do lamento por Saul.

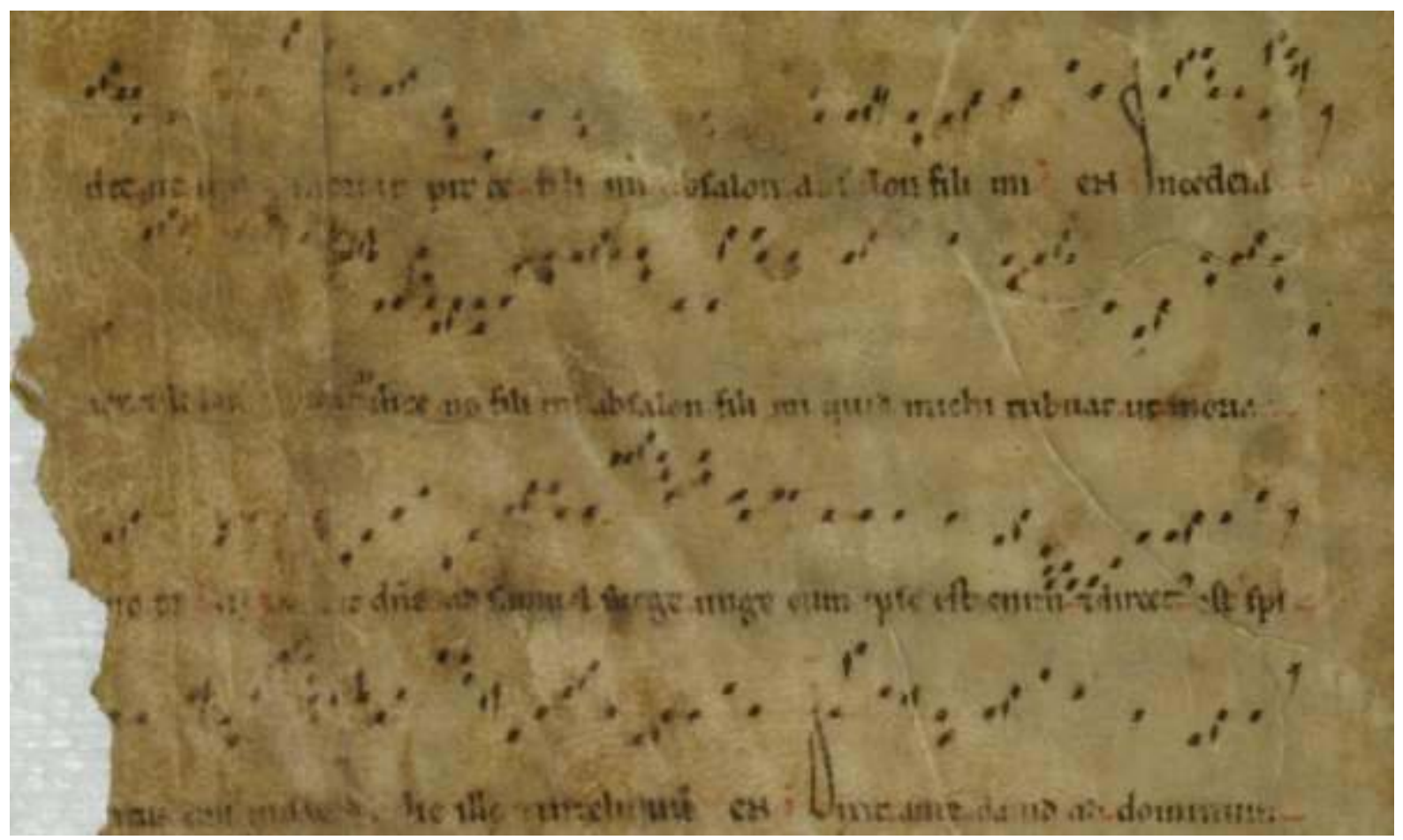

Ex. 7 - A antífona «Incedens rex», na sequência de «Rex autem», no fragmento 732 do Arquivo Distrital de Viseu

«David sedens in cathedra»: glorifica os companheiros de David distinguidos em batalha, prefigurando a desejada cumplicidade e submissão da classe guerreira à liderança da Igreja. 
«Appropinquaverunt autem dies»: ao focar o momento da passagem de testemunho entre David e Salomão, reforça a convicção de continuidade messiânica entre a linhagem de David e o Cristo redentor, representado pela classe sacerdotal.

Destas cinco antífonas, duas («Et ait dominus»e «Incedens rex») tiveram larga divulgação em Portugal, através de livros da família aquitano-cluniacense, que estiveram na base do costume da catedral de Braga (por exemplo, o antifonário do Arquivo capitular de Toledo, com a cota 44.2). Para além de presentes no breviário de Soeiro e no primeiro breviário bracarense impresso, encontram-se também, com a respectiva música, num fragmento pergamináceo do século XII conservado no Arquivo Distrital de Viseu (Cabido da Sé, capa do Livro 303/732, olim 778: aqui parcialmente reproduzido). Como se pode verificar no quadro seguinte, estas novas antífonas não foram retidas no costume eborense, e só uma delas se cantava no mosteiro de Pedroso em Gaia (Torre do Tombo, OSB, São Pedro de Pedroso, maço 43, $\mathrm{n}^{\circ} 5$, capa). Num outro fragmento medieval, encontrado no Arquivo Distrital de Braga (Pastas de fragmentos, $\mathrm{n}^{\circ} 13$ ), falta a parte que presumivelmente as incluiria ${ }^{17}$.

\begin{tabular}{|l|l|l|l|l|}
\hline Braga (+ Toledo 44.2) & Évora & Pedroso & ADB 13 & ADV 732 \\
\hline & & & & \\
\hline 1: Cognoverunt omnes & 1 & & + & \\
\hline 2: Nonne iste est David & 2 & & + & \\
\hline 3: Prevaluit David & 3 & & + & \\
\hline 4: Iratus rex Saul dixit & 4 & & & \\
\hline 5: Quis enim in omnibus & 5 & & & \\
\hline 6: Montes Gelboe & 6 & {$[+]$} & + & {$[+]$} \\
\hline 7: Saul et Ionathas & 7 & + & + & + \\
\hline 8: Planxit autem & 8 & + & + & + \\
\hline 9: Doleo super te frater & 9 & + & + & {$[+]$} \\
\hline 10: Rex autem David & 10 & + & {$[+]$} & + \\
\hline
\end{tabular}

\footnotetext{
${ }^{17}$ Sobre estas antífonas, veja-se: Jacques DUBOIS, «Comment les moines du Moyen Age chantaient et goûtaient les Saintes Ecritures», in Le Moyen Age et la Bible, ed. Pierre Riché \& Guy Lobrichon, Paris: Beauchesne, 1984, pp. 261-98. Ruth STEINER, «David's Lament for Saul and Jonathan», in Commemoration, Ritual and Performance: Essays in Medieval and Early Modern Music, ed. Jane Morlet Hardie with David Harvey, Ottawa: Institute of Mediaeval Music, 2006, pp. 5-15. Manuel Pedro FERREIRA, «Cluny at Fynystere: One Use, Three Fragments», in Studies in Medieval Chant and Liturgy in Honour of David Hiley, ed. Terence Bailey \& László Dobszay, Ottawa - Budapest: The Institute of Mediaeval Music / Hungarian Academy of Sciences, 2007, pp. 179-228.
} 


\begin{tabular}{|l|l|l|l|l|}
\hline 11: Incedens rex * & - & - & & + \\
\hline 12: Et ait Dominus * & - & + & & + \\
\hline 13: Dixit autem David & 11 & + & & + \\
\hline 14: Obsecro Domine aufer & - & + & & \\
\hline 15: Unxerunt Salomonem & 12 & + & {$[+]$} & \\
\hline 16: Salomon fili mi scito & - & + & {$[+]$} & \\
\hline 17: Vade ad Iordanem * & - & + & + & \\
\hline $\begin{array}{l}\text { (18: Appropinquaverunt)* } \\
\text { (19: Clamabat Eliseus) }\end{array}$ & - & - & - & \\
\hline $\begin{array}{l}\text { (20: Audi Domine } \\
\text { hymnum)* }\end{array}$ & - & - & - & \\
\hline
\end{tabular}

* antífonas não incluídas no Corpus antiphonalium officii

Ex. 8 - Presença de antífonas de Regum em diversas fontes portuguesas

Devido à influência humanística, no início do século XVI registar-se-ia um renovado interesse por alguns destes textos; com ou sem alteração, foram então usados como fontes para motetes polifónicos. De facto, os lamentos de David por Saul e Jónatas ou pelo filho Absalão viriam a suscitar, devido ao seu poder emotivo, várias composições originais, cuja autoria apresenta alguns problemas de atribuição: Planxit autem David (Josquin des Près?), Considera Israel (Pierre de la Rue), Absolon fili mi (Pierre de la Rue ou Josquin des Près?), Lugebat David Absalom (Nicolas Gombert?), Rex autem David (Mathieu Gascogne), exemplos a que se seguiram, em meados do século, muitos outros, envolvendo compositores de maior ou menor gabarito (Clemens non Papa entre eles) ${ }^{18}$. Há duas outras versões inéditas, anónimas, do Rex autem, para quatro vozes, nas fontes quinhentistas portuguesas.

\footnotetext{
${ }^{18}$ R. STEINER, cit; Richard SHERR (ed.), Motets on Texts from the Old Testament, 1 [New Josquin Edition, vol. 14], Utrecht: Koninklijke VNM, 2002; Martin PICKER (ed.), The Motet Books of Andrea Antico [Monuments of Renaissance Music 8], Chicago: The University of Chicago Press, 1987; Ellen S. BEEBE, «Why Clemens non Papa did not need a 'Secret Chromatic Art'», in Musical Humanism and its Legacy: Essays in Honor of Claude V. Palisca, ed. Nancy K. Baker \& Barbara R. Hanning., New York: Pendragon Press, 1992, pp. 213-40.
} 


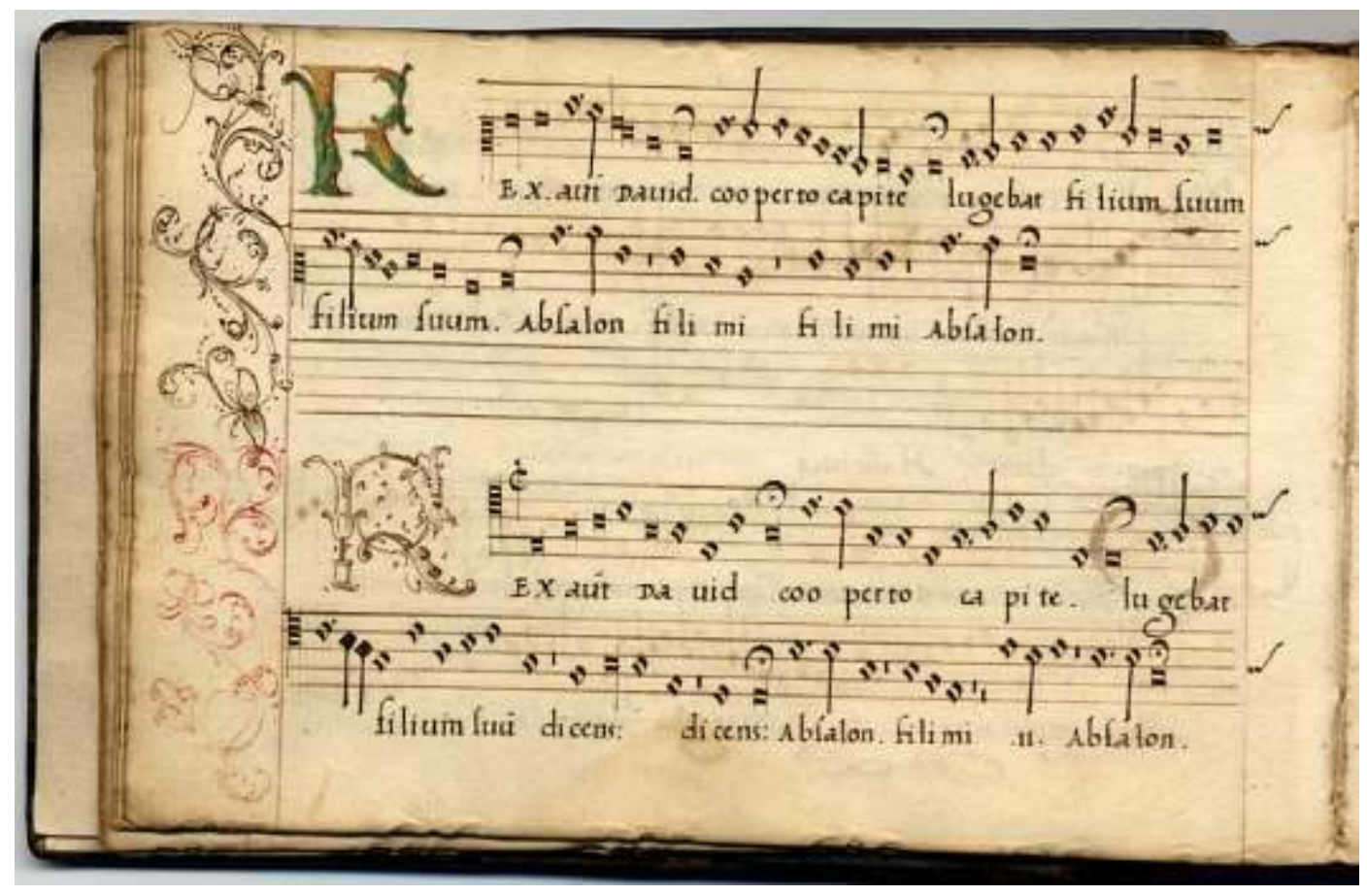

Ex.9 - O início de uma versão polifónica anónima de Rex autem David no códice miscelâneo da Biblioteca Nacional, CIC 60

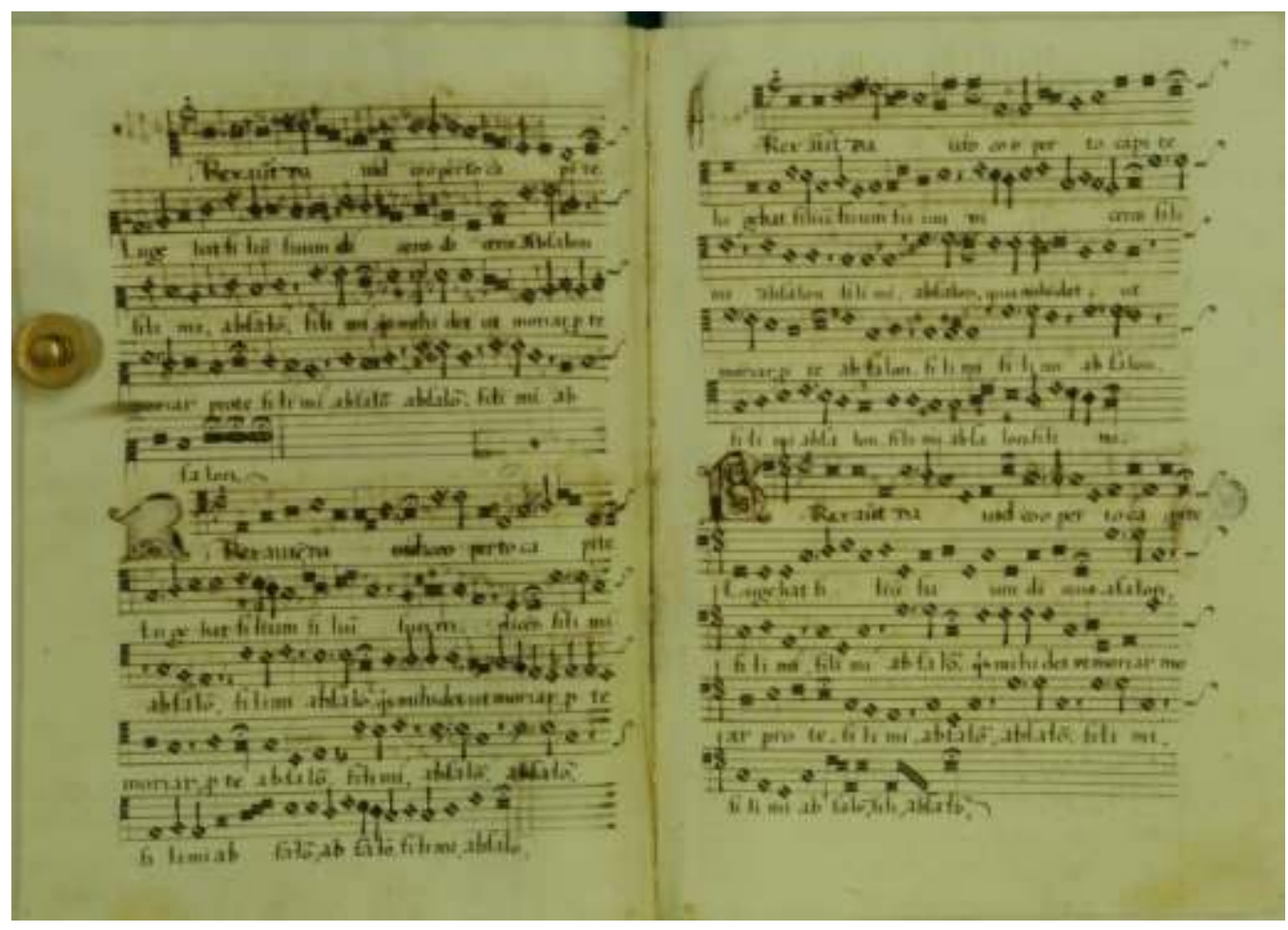

Ex. 10 - Outra lição do mesmo Rex autem no manuscrito MM 32 da Universidade de Coimbra 
Trata-se de motetes curtos, cujo texto reproduz, em geral, o da respectiva antífona em cantochão:

«E o rei David, caminhando de cabeça coberta, lamentava o filho, dizendo: Absalão filho meu, meu filho Absalão, quem me dera que eu morrera por ti, ó meu filho Absalão!»

Um destes motetes, presente em três fontes ligadas a Coimbra (B.N., CIC 60; B.G.U.C., MM 32 e MM 48) usa, como o de Gascogne, uma variante do texto («lamentava o seu filho») que, nas fontes monódicas, só ocorre, no estado actual do nosso conhecimento, em manuscritos do centro ou do norte da Europa ${ }^{19}$. Para além disso, omite a referência ao andar do rei: Rex autem David cooperto capite lugebat filium suum dicens Absalon fili mi, etc. O motete restante ocorre só no manuscrito de Coimbra MM 48, e o texto, com excepção de um aportuguesamento pontual do latim, corresponde à antífona gregoriana na sua versão mais corrente:

Rex autem Davit cooperto capite incedens

lugebat filium dicens: Absalon fili [mi, fili mi Absalon], quis mihi det ut ego moriar pro te, fili mi Absolão. (sic)

${ }^{19}$ Cf. CURSUS, An Online Resource of Medieval Liturgical Texts [www.cursus.uea.ac.uk]: Critical Edition of Antiphon c4650. 


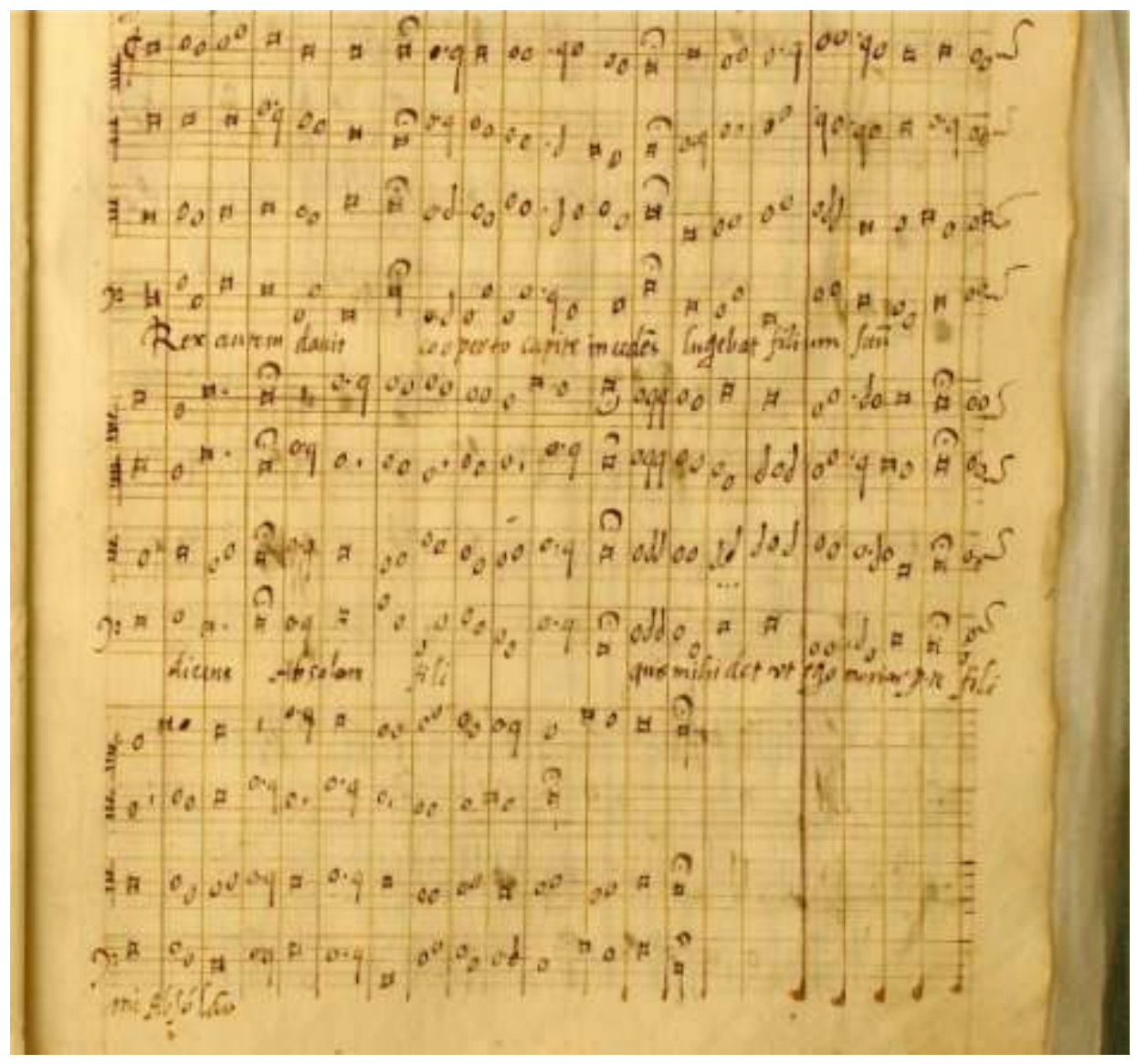

Ex. 11 - Outra versão de «Rex autem» no códice MM 48, também da Universidade de Coimbra.

É talvez significativo que todas as fontes tenham ligações a Coimbra, e particularmente ao mosteiro de Santa Cruz, conhecido pelo interesse com que, no segundo quartel do século XVI, promoveu o conhecimento dos textos e das línguas clássicas e do ideário humanístico em geral. Também é significativo que o motete mais divulgado nos manuscritos tenha presumivelmente, a julgar pelas variantes textuais, uma origem não-peninsular. A moda musical, assim como a intelectual, provinha então da zona franco-flamenga, tal como, por volta do ano 800, a renovação musical e intelectual haviam conhecido uma espécie de epicentro na proximidade de Metz e Aachen, onde se construiu o palácio de Carlos Magno, com a sua magnífica capela. 


\section{David nos tropos e sequências da Missa}

De facto, a época de Carlos Magno testemunhou, em parte por impulso deste último, transformações profundas e duradouras na cultura europeia. Uma delas foi a formação final do rito romano-franco, baseado em textos importados de Roma, mas completado por outros de tradição galicana, tradição que forneceu igualmente, até certo ponto (ainda não determinado), o estilo musical que conhecemos por «gregoriano». No início do século IX estavam definitivamente fixados os textos fundamentais da Missa (cânticos próprios e ordinários) e os contornos melódicos das peças mais complexas, confiadas a um grupo restrito de cantores, enquanto o Ofício divino, a partir de um núcleo comum, permanecia ainda, em larga medida, em estado de fluxo. A teoria modal bizantina foi introduzida na mesma época. É significativo que Alcuíno tenha então descrito Carlos Magno como um novo David, e o professor de música da sua capela, cujo nome se desconhece, como um novo Idutun, músico do Templo referido nas Crónicas do reinado de David (I Par. 16:41-42, 25:1-3) ${ }^{20}$. Sobre os textos de antigamente, era uma nova salmodia, em sentido lato, que nascia para a Europa.

Para além da progressiva expansão do repertório do Ofício divino, e da composição de novas melodias para o Aleluia ou para os cantos ordinários da Missa (Kyriale), os clérigos da época pós-carolíngia abriram outras vias para a criatividade litúrgica: a introdução de expansões melismáticas, a produção de textos novos para melismas pré-existentes, ou a invenção de unidades literário-musicais para enquadrar ou intercalar em cânticos de maior antiguidade. Deste fenómeno artístico, formal e exegeticamente afim à glosa bíblica, nasceram os tropos (de intróito, de ofertório, de Kyrie, etc.), e o caso particular das sequências de Aleluia.

O intróito da Missa foi um dos géneros musicais que mais atraíram os tropos, pela solenidade da respectiva procissão, pela sua função introdutória de apresentação do sacerdote enquanto representante de Cristo na Terra, e pelo facto de serem teológica e liturgicamente pouco explícitos em relação à prefiguração da mensagem cristã como à ocasião que sinalizavam, por usarem quase sempre textos do Antigo Testamento. Os tropos de intróito que aludem a David pretendem normalmente sublinhar a dignidade messiânica da linhagem de Jesus. Assim, o texto do intróito para a $3^{a}$ Missa do Natal, «Puer natus», baseado em Isaías, afirma somente: «Uma criança nasceu para nós e um filho nos foi dado; a insígnia do seu poder repousa sobre os seus ombros. E chamar-lhe-ão anjo do grande conselho.» No sul de França, passou a cantar-se deste modo:

$<$ Deus pater filium suum hodie misit in mundum,

\footnotetext{
${ }^{20}$ David HILEY, Western Plainchant: A Handbook, Oxford: Clarendon Press, 1995, p. 522.
} 
de quo gratulanter dicamus cum propheta:>

PUER NATUS EST NOBIS ET FILIUS DATUS EST NOBIS,

<qui sedebit super tronum David et in eternum imperabit,>

CUIUS IMPERIUM SUPER HUMERUM EIUS.

$<$ Ecce venit Deus et homo de domo David sedere in trono,>

ET VOCABITUR NOMEN EIUS,

<eo quod futura annunciabit,>

MAGNI CONSILII ANGELUS.

Ou seja,

«Deus Pai seu filho hoje pôs no mundo;

alegremente cantemos, pois, com o profeta:

UMA CRIANÇA NASCEU PARA NÓS E UM FILHO NOS FOI DADO,

que se sentará no trono de David e reinará eternamente;

A INSÍGNIA DO SEU PODER REPOUSA SOBRE OS SEUS OMBROS.

Ei-lo que vem, Deus e homem da casa de David, sentar-se no trono,

E CHAMAR-LHE-ÃO

- pois o futuro ele anunciará -

ANJO DO GRANDE CONSELHO ${ }^{21}$.

A mesma ideia foi aplicada ao intróito do dia de Epifania, «Ecce advenit». A linhagem davídica é também um dos temas focados nos tropos marianos, muito populares no sul de França entre os séculos X e XII. Se a presença do tema não surpreende na festa da Purificação a 2 de Fevereiro (originalmente parte do ciclo natalício, como comemoração da Apresentação de Jesus no Templo e do seu encontro com Simeão), ele emerge sobretudo nos tropos dos intróitos «Gaudeamus» ou «Gloriosae virginis», para a festa da Natividade da Beata Virgem Maria ${ }^{22}$.

A linhagem davídica de Maria é também glosada em textos compostos para a repetição do Aleluia: as «sequências» musicais, ou «prosas». Em Missas para as festas marianas, era frequente esse tipo de expansão literária e musical. Em «Mater clemens ac benigna», por exemplo, diz-se de Maria:

\footnotetext{
${ }^{21}$ Bruno STÄBLEIN, Introitus-Tropen I. Das Repertoire der südfranzösischen Tropare des 10. und 11. Jahrhunderts [Monumenta Monodica Medii Aevi, Band III], Kassel: Bärenreiter, 1970. Sobre os tropos de intróito, veja-se Gunilla IVERSEN, Chanter avec les anges: poésie dans la messe médiévale interprétations et commentaires, Paris: Éditions du Cerf, 2001, pp. 45-74. Veja-se também, sobre as implicações políticas e iconográficas dos tropos davídicos, Janet T. MARQUARDT-CHERRY, «King David in Germany: Royal Traditions at Prüm», Essays in Medieval Studies, vol. 9 (1992), pp. 41-47.

${ }^{22}$ Cf. Ann-Katrin Andrews JohAnsson, Tropes for the Proper of the Mass 4: The Feasts of the Blessed Virgin Mary [Corpus Troporum IX], Stockholm: Almqvist \& Wiksell, 1998.
} 
«Da estirpe de David plantada,

por eleitos anunciada,

permanece sempre intacta,

de Sião a porta ornada. ${ }^{23} \gg$

A linhagem davídica aparece também referida em sequências destinadas a diferente contexto litúrgico. Em «Quam dilecta tabernacula», para a dedicação de uma igreja (missa inaugural), o autor explora o tema da substituição do antigo Templo de Jerusalém pelo culto cristão. Cada novo santuário é o legítimo continuador do precedente; nele toda a história do Antigo Testamento (que prefigura, anuncia e se cumpre através do Novo) estará presente, aqui e agora, para todo o sempre. Deste modo, tal como os horrores da revolução industrial eram lembrados pelo marxismo enquanto «necessidade histórica» conducente à ditadura do proletariado, os acidentes morais da história de David, enquanto condição necessária ao Advento de Jesus, ganham na igreja, no decurso da celebração ritual, uma nova actualidade:

«Aqui de Urias enviuvou

Betsabé, e se elevou

ao lugar de consorte régia» ${ }^{24}$.

Apesar do impulso criativo pós-carolíngio, houve sectores da Igreja que se opuseram à introdução na liturgia de textos não-bíblicos. A posição radical de Agobardo de Lião teve algum eco no mosteiro de Cluny, que restringiu fortemente o uso de sequências e não acompanhou a moda dos tropos. No entanto, a posição conservadora de Cluny não se estendeu a outros mosteiros beneditinos pertencentes à sua família, especialmente no sul de França, onde a tradição local continuava a ditar a lei. Para isto terá contribuído a simpatia cluniacense pela elaboração solene do rito e pelos efeitos benéficos da arte musical.

\footnotetext{
${ }^{23}$ Sobre o texto desta sequência, veja-se Gunilla IVERSEN, Chanter avec les anges, cit., pp. 183-89.

${ }^{24}$ Hic Urias viduatur, / Bersabee sublimatur / sedis consors regie. Sobre o texto da sequência «Quam dilecta tabernacula», veja-se Gunilla IVERSEN, «Biblical Interpretation in Tropes and Sequences», The Journal of Medieval Latin, vol. 17 (2007), pp. 210-25 [221-24].
} 


\section{David no debate estético do século XII}

Na verdade, o exemplo de David foi invocado por vários autores não só para exemplificar os poderes terapêuticos da música, mas também para justificar a atenção dada na Igreja ao canto e à sua elaboração artística. Assim, no início do século X, Odão, o influente abade de Cluny, defendeu, contra as objecções de alguns, o deleite estético oferecido pela música vocal da Igreja:

«É verdade que o beato Agostinho assevera no seu livro de Confissões que incorre em pecado aquele que, ao escutar os responsórios divinos, se deleita mais na modulação do que no sentido das palavras. Também São Jerónimo, na sua [discussão da] Epístola [de S. Paulo] aos Efésios, disse que na igreja não é suposto cultivar a garganta e adornar as vozes com modulação suave ou mesmo teatral, porque deve cantar-se a Deus não com a voz mas com o coração. Nós, pelo contrário, pensamos que a modulação se dirige mais a ouvidos humanos do que a divinos, já que o uso da salmodia foi instituído para este fim: tal como David tocando a cítara expulsou de Saul o espírito maligno (I Sam. 16:23), do mesmo modo os cantores, através da modulação, expulsam quaisquer desejos diabólicos dos corações dos que os escutam» ${ }^{25}$.

Esta mesma linha de pensamento, em que a música é apresentada como meio de santificação espiritual da audiência, seria retomada no século XII por João de Salisbúria, aluno de Abelardo, que acabou por ser bispo de Chartres depois de, por duas décadas, ter servido os arcebispos de Cantuária como seu secretário. No Policraticus, texto escrito na década de 1150, refere os louvores com que os santos Padres exaltaram a música, argumentando de seguida que

«pela sua virtude a violência do espírito maligno é coibido, e graças à música o seu poder sobre os que sujeita é minorado. Pois quando o mau espírito tomou Saul, David tocou na cítara que tinha entre mãos, até que o espírito deixou de atormentar o rei.»

O efeito terapêutico da música é seguidamente explicado pelo facto de, segundo opinião generalizada, a alma se compor de consonâncias musicais. Quando a sua tranquilidade natural é perturbada por factores corporais ou pelo tumulto exterior, o contacto com a harmonia musical permite que a alma, por empatia, volte a si. Segundo o autor, esta harmonia, não sendo espírito,

25 OdDONIS abbatis Cluniacensis, Collationum libri tres, in J. P. Migne (ed.), Patrologiae cursus completus, series latina, t. 133, Paris: Garnier, 1881, cols. 517A-638C [II.xvii: 564C]. Minha tradução. 
é de algum modo o seu veículo; e consigo transporta ora o espírito humano, ora o divino, ora o profético. As potencialidades da concordância sonora são seguidamente expostas:

«Quando, na verdade, se apresenta colorida dos modos mais delicados, a sua beleza cativa até mentes severas, e a tristeza expulsa, ao induzir uma espécie de grácil jovialidade. E se porventura se ficar dominado por alguma distracção ou perturbação ou nebulosa cogitação, tem o poder de a dissipar.»

A defesa dos benefícios espirituais alcançados pela subtil variedade de cores musicais não é original, podendo relacionar-se, por exemplo, com o capítulo XIV do tratado Micrologus, do italiano Guido d'Arezzo, no qual se apresenta a variedade de modos como correspondente a uma agradável profusão de cores, odores e sabores. Mas João de Salisbúria vai mais longe:

«Assim, para edificação dos costumes e atrair, pelo festejo da virtude, as atenções sobre o culto divino, os santos Padres foram da opinião, quando procuravam dilatar a reverência pelo Templo, de que não só a modalidade coral, como as modalidades instrumentais deveriam ser postas ao serviço do Senhor. E se te parece pequena a autoridade da Igreja militante, ou se os louvores à música da Igreja triunfante em ti não encontram eco, o Filho do trovão viu os seus anciãos, e a ti os mostrou, e as suas vozes eram como vozes de citaredos citarizando em suas cítaras (Apoc. XIV:2). Mas se ainda os não ouviste, ouve o rei exultante, que te quer participante no seu reino e na sua exultação, pois disse: "Entoai o Salmo, e tocai os tambores: saltério e cítara em alegre harmonia" (Ps. 80). Para quê, perguntarás; para que louves o Senhor "com o pandeiro e com a dança; com o pulsar das cordas e o soar dos tubos" (Ps. 150).»

Aqui David, como autor presumido dos Salmos, profeticamente investido da voz de Cristo, é mobilizado para sustentar a defesa da música instrumental dentro da Igreja. Apesar da conhecida relação de David com a prática instrumental, a presença de instrumentos no coro eclesiástico era uma novidade relativa. Ausentes do recinto sagrado nos primeiros séculos de cristianismo, vigorosamente condenados fora dele por razões de moralidade sexual ${ }^{26}$, seriam introduzidos na igreja, a partir do século IX (se não antes), para apoio às aulas de música. Os instrumentos de corda ficariam associados às novas composições poéticas (versus, tropos, sequências); o órgão, a pouco e pouco, iria ganhar protagonismo alternando com o canto

${ }^{26}$ Cf. James MCKInNON, The Temple, the Church Fathers and Early Western Chant, Aldershot: Ashgate, 1998. 
litúrgico $^{27}$. No século XII, antes que várias proibições deixassem o órgão como único instrumento tolerado nas igrejas, as opiniões dividiam-se quanto à admissibilidade dos instrumentos em geral. João de Salisbúria defende-os, mas passa seguidamente a lamentar a corrupção e contaminação da disciplina musical por diversas afectações estilísticas, bem como a recente popularidade, entre homens sérios, das cançonetas de amor. Denuncia, enfim, aqueles que desonram o culto religioso, já que

«no mais recôndito do santuário, na presença de Deus, com a indolência de uma voz afectada, uma certa ostentação de si, uns modos efeminados na emissão das notas e no recorte das frases, procuram atordoar e amolecer as almas simples. Se pudesses ouvir as dulcíssimas modulações que no canto ora precedem, ora respondem, ora concordam, ora divergem, ora intercalam, ora contrapõem, julgarias estar perante um coro de sereias, e não de homens, e ficarias maravilhado com a facilidade vocal, que não encontra rival nem em rouxinol ou papagaio, nem noutro pássaro qualquer de maior sonoridade. Pois tal é a sua destreza tanto em subir como em descer, na subdivisão ou geminação das notas, na repetição de frases e consolidação de frases individuais - combinando assim devidamente o agudo, ou sobre-agudo, com o grave e o sub-grave - , que os seus ouvidos quase perdem o poder de julgamento, e a alma, que se deixou encantar por tanta suavidade, é incapaz de examinar os méritos do que ouviu. Quando este modo de cantar cai no excesso, é capaz de suscitar mais a excitação do baixo-ventre do que a devoção da mente; mas se, na verdade, se mantiver nos limites regrados da moderação, resgata a alma de preocupações, cancela as solicitações temporais, e de certo modo, pela partilha de calma e de alegria e pelo festejo benevolente em Deus, transporta os espíritos humanos para a companhia dos anjos» ${ }^{28}$.

Assim, apesar de condenar os excessos, João de Salisbúria é sensível ao efeito estético do virtuosismo vocal, bem como da polifonia organal, que se praticava desde o século IX (e que pode de facto ser entendida como uma «consolidação» harmónica da melodia, com desdobramento das vozes em vários registos, formando consonâncias à distância de um quarta, de uma quinta ou de uma oitava perfeitas).

\footnotetext{
${ }^{27}$ Michel Huglo, «Deux séquences de musique instrumentale», Revue de musicologie, 76/1 (1990), pp. 77-82.

${ }^{28}$ Ioannis Saresberiensis Episcopi Carnotensis Policratici, sive De nugis curialium et vestigiis philosophorum Libri VIII, ed. Clemens C. I. WEBB, Oxford: Clarendon Press, 1909, Tom. I [Lib. I, cap. vi - De musica et instrumentis et modis et fructu eorum: pp. 39-44]. Outra edição: JoANNIS Saresberiensis, Polycraticus, in J.-P. MigNE (ed.), Patrologiae cursus completus, series latina, vol. 199. Paris: J.-P. Migne, 1855, cols. 385-822; [I.vi: 401A-404C]. Minha tradução.
} 
Havia, contudo, uma corrente de opinião muito crítica de todas as formas de artificiosismo musical. Um cónego da regra de S. Agostinho, Hugo de Fouilloy, que foi lido em vários mosteiros cistercienses portugueses ${ }^{29}$, ecoa os autores patrísticos, denunciando nos seus escritos aqueles que cantilam os Salmos sem os pensar:

«Há alguns que, de mente distraída, olhos pasmados, postura indolente, examinam as paredes planas percorrendo-as demoradamente com o olhar, cantando uma coisa e pensando noutra. O corpo está no coro, mas a mente na praça; ora estão dentro, ora saem para fora; não só são frouxos no íntimo, como são indiscretos logo que se ausentam. Da salmodia proferem as palavras, mas não atendem ao seu sentido.»

$\mathrm{O}$ autor prossegue, assumindo a posição de S. Jerónimo segundo a qual as vozes da salmodia se dirigem primordialmente não aos homens, mas a Deus. Inova, contudo, quando acautela os clérigos para o perigo de transformarem o mosteiro num teatro, através da valorização dos próprios dotes vocais e improvisatórios. A crítica patrística da música teatral ou de banquete pressupunha que ela permanecia no seu espaço próprio; comentadores posteriores como Odão de Cluny ignoraram esse pormenor. Agora, para enriquecer o arsenal literário de combate às novas práticas musicais da igreja, estas são retoricamente associadas ao ambiente social condenado por Tertuliano, Clemente de Alexandria ou S. João Crisóstomo, embora esse ambiente estivesse então defunto há séculos:

«Há ainda outros de voz dissoluta, que se vangloriam das suas modulações vocais, e não somente se comprazem em ter recebido um dom mas também, inchados pelo orgulho, desdenham os restantes; cantam algo diverso do que têm nos livros, e outra coisa porventura de novo têm vontade de dizer, se acaso ao mesmo ponto retorna também novamente o canto. Tanta é a ligeireza da voz, como, talvez, a da mente. Cantam, acaso, de modo que agradem mais ao povo do que a Deus. Os que assim cantam, não cantam com Maria irmã de Moisés, mas no palácio com Herodíades, agradando aos convivas ou a Herodes. Receio ainda que tal como se deleitam na altura da voz, decerto se deleitem na arrogância da mente. Ninguém todavia canta mais alto do que Deus, do seu santo monte, costuma ouvir; ninguém canta mais docemente do que aquele para quem o Senhor apura os seus ouvidos. "Com a minha voz, diz David, clamei ao Senhor, e Ele

\footnotetext{
${ }^{29}$ José MATTOSO, «Leituras cistercienses do século XV», in id., Religião e Cultura na Idade Média portuguesa, Lisboa: Imprensa Nacional - Casa da Moeda, 1982, pp. 511-52.
} 
ouviu-me desde o seu santo monte" (Ps. 3:5). Sejas pois no vale da humildade, para que mereças ser ouvido no santo monte» ${ }^{30}$.

Esta crítica moral tem por horizonte uma experiência concreta, mas aquilo que nela se denuncia é, em certa medida, intrínseco à prática vocal e à dinâmica social em contexto coral: a desigualdade do talento individual, os limites da disciplina colectiva, a concorrência pelos papéis mais destacados, a possibilidade de exploração do espaço sonoro e da variabilidade formal das peças pelos cantores mais afoitos. Não se pode impedir vozes confiantes de vozearem livremente, de medirem os seus limites, de se medirem entre si; mas para Hugo de Fouilloy, isso contraria o auto-apagamento que assume como modelo de vida clerical; e quem aparece a propugnar esse ideal é, ainda e sempre, David.

Hugo é, apesar de tudo, um crítico comedido, comparado com a verve do cisterciense Elredo de Rieval, quando n'O espelho da caridade (1141-1142) decide atacar «o vão deleite dos ouvidos». Quanto a instrumentos, não poupa nem o órgão, nem o pequeno carrilhão de mão; e quando fala de cantores, ficamos com a sensação de termos perdido um espectáculo verdadeiramente notável na sua riqueza ornamental, textural e expressiva - a ponto de se poder duvidar do seu valor como testemunho descritivo ${ }^{31}$ :

«Tratemos agora desses que, sob a capa da religião, procuram a ocupação prazenteira; esses que usurpam, para colocar ao serviço da sua vaidade, o que os antigos sacerdotes [do Templo] empregavam saudavelmente, como prefiguração do mundo futuro. Mas se [após a vinda do Messias] já não têm razão de ser esses símbolos e essas figuras, porquê na Igreja tantos órgãos, tantos sinos? Para quê, insisto, esse terrível soprar dos foles, que mais imita o fragor do trovão do que a suave expressão das vozes? Para quê essa contracção e subdivisão da voz? Um cantor soa sub-reptício, aquele junta-lhe outra voz, aqueloutro sobressai no agudo, e outro ainda introduz e multiplica notas de passagem. Umas vezes o canto comprime-se, outras requebra-se; umas vezes engorda, outras estira-se num som interminável. Às vezes, é vergonhoso dizê-lo, a voz sai forçada como rinchos de cavalo; e às vezes, prescindindo do vigor varonil, ascende em primores efeminados, quando não se enrola e enreda em circunvoluções artificiosas. Não é raro ver um homem boquiaberto, parecendo sufocar, não cantando mas ameaçando silêncio

${ }^{30}$ Hugo Folietanus, De claustro animae libri quatuor, in J. P. Migne (ed.), Patrologiae cursus completus, series latina, t. 176 [aí atribuído a Hugo de S. Victor], Paris: Garnier, 1880, cols. 1017-1182 [II.xxii - De dissolutione in choro. Abusio undecima: 1080]. Minha tradução.

${ }^{31}$ É a opinião, por exemplo, de John DYER, «The voice in the Middle Ages», in The Cambridge Companion to Singing, ed. John Potter, Cambridge: Cambridge University Press, 2000, pp. 165-77 [175]. 
com ridículas intercepções da voz; ou imitando a agonia dos moribundos ou o estupor dos doentes. De vez em quando agita-se o corpo todo com gestos histriónicos, revolvem-se os lábios, giram os olhos, erguem-se os ombros, e a cada nota responde uma flexão dos dedos. E a esta ridícula dissolução chamam religião; e onde com mais frequência isto acontece, é aí onde se proclama que mais honradamente se serve a Deus» ${ }^{32}$.

Em suma, para este autor cisterciense a arte interpretativa, na música eclesiástica, é moralmente suspeita. Esta posição não surpreende no seio de uma Ordem que, nessa mesma época, investia imenso tempo e esforço a fixar um texto musical invariável, objectivo, exactamente reprodutível, despido de inconsistências teóricas e despojado de excessos melismáticos: a primeira edição musicológica sistemática do canto gregoriano no seu conjunto, promulgada por S. Bernardo ${ }^{33}$.

Para os cistercienses, o David músico era visto pelo prisma alegórico, ou quando muito pelo prisma pitagórico, curando almas feridas por via da pura racionalidade musical. Não havia lugar para o David emotivo, que dançava e tocava à entrada de Jerusalém, ou que chorava desconsolado, entoando um pranto por Saul e Jónatas, porventura «imitando a agonia dos moribundos». Este era, pelo contrário, o David de Abelardo, mestre tornado célebre pela sua lógica dialéctica; um mestre tornado monge que se orgulhava dos seus dons poético-musicais, e que, depois de declarado herético por S. Bernardo e condenado ao silêncio pelo papa em 1140, foi protegido por Pedro o Venerável, abade de Cluny ${ }^{34}$. Esse David emotivo era aquele que, na linha da sensibilidade estética cluniacense, Abelardo havia recriado nos prantos «Abner fidelissime», pela morte de Abner (II Sam. 3:33-34), e «Dolorum solatium», pela morte de Saul e Jónatas.

Ambos os lamentos nos chegaram transcritos com neumas musicais: um apontamento de carácter esquemático, com valor mnemónico para quem sabia de cor as melodias, mas insuficiente para quem nunca as houvesse aprendido. Felizmente, o último destes prantos tornou-se suficientemente popular para se conservar noutros dois manuscritos, apontados de forma a especificar a altura das notas, o que nos permite hoje em dia recriar a sua execução musical:

\footnotetext{
32 AELREDI Rievallensis, De speculo caritatis, in Opera Omnia, 1: Opera Ascetica, ed. A. Hoste \& C. TALBOT (Corpus Christianorum, CM 1), Turnhout: Brepols, 1971 [II.xxiii: pp. 97-99]. Minha tradução.

33 Manuel Pedro FERREIRA, «La réforme cistercienne du chant liturgique revisitée: Guy d'Eu et les premiers livres de chant cisterciens», Revue de Musicologie, Tome 89 (2003), nº 1, pp. 47-56.

${ }^{34}$ Cf. Michael T. ClanCy, Abélard, Paris: Flammarion, 2000, capítulo 13.
} 


\begin{tabular}{|c|c|}
\hline Dolorum solatium & Ó consolação de dores, \\
\hline laborum remedium & ó remédio de labores, \\
\hline mea michi cithara & harpa minha, para mim: \\
\hline nunc, quo maior dolor est & sendo mais agora a dor \\
\hline iustiorque meror est, & — a tristeza quer-se impôr- \\
\hline plus est necessaria. & é mais que precisa, enfim. \\
\hline Strages magna populi, & Grande massacre da grei; \\
\hline regis mors et filii, & com seu filho, morto o rei; \\
\hline hostium victoria, & vitória de hostil hoste; \\
\hline ducum desolatio, & os líderes desolados, \\
\hline vulgi desperatio, & o vulgo desesperado; \\
\hline luctu replent omnia. & o luto a tudo cobre. \\
\hline Amalech invaluit & É Amaleque fortificado \\
\hline Israhel dum corruit: & enquanto Israel é derrubado. \\
\hline infidelis jubilat Philistea, & A Filisteia infiel rejubila \\
\hline dum lamentis macerat se Judea. & enquanto em lamentos Israel se humilha. \\
\hline Insultat fidelibus & Aos fiéis insulta, \\
\hline infidelis populus. & infiel, a turba. \\
\hline In honorem maximum plebs adversa, & O inimigo, ao máximo honram, \\
\hline in derısum omnıum fit divina. & e do divino, já todos zombam. \\
\hline Insultantes inquiunt - & Diz quem insulta: «eis como aquele \\
\hline ecce de quo garriunt, & de que palravam, o deus deles, \\
\hline qualiter hos prodidit deus suus, & os abandonou, pois deuses variados \\
\hline dum a multis occidit dis prostatus. & matam o único, o derreado. \\
\hline Quos primum his prebuit & Aquele a quem ele deu \\
\hline victus rex occubuit. & primazia, o rei vencido, faleceu. \\
\hline
\end{tabular}




\begin{tabular}{|l|l}
\hline Talis est electio dei sui, & Tal foi do seu deus a eleição, \\
talis consecratio vatis magni. & tal do profeta a consagração. ${ }^{35}{ }^{~}$
\end{tabular}

Ouçamos, neste lamento de Abelardo - em que as passagens contemplativas iniciais, algo estáticas, são melodicamente expandidas, e o ritmo narrativo central encontra resposta na concisão silábica —, a emoção de David transposta em música, encontrando eco, por séculos e séculos, na experiência e no espírito dos homens.

\section{COMO CITAR ESTE ARTIGO}

Referência electrónica

FERREIRA, Manuel Pedro - "Recordando o rei David: vivência coral e criatividade musical na Europa pós-carolíngia". Medievalista [Em linha]. No8, (Julho de 2010). [Consultado dd.mm.aaaa]. Disponível em http://www2.fcsh.unl.pt/iem/medievalista/MEDIEVALISTA8lferreira8005.html. ISSN 1646-740X.

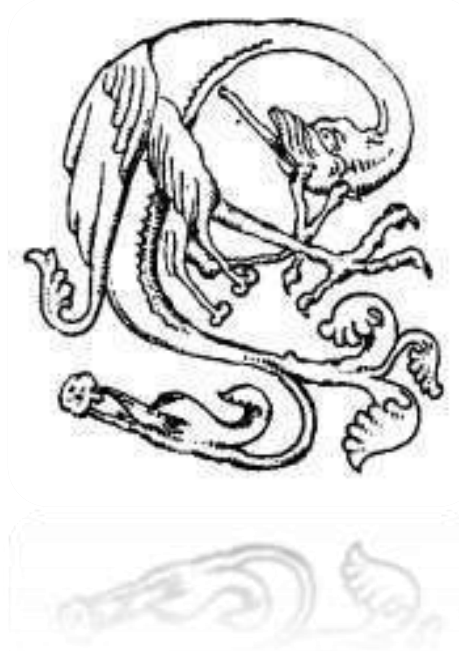

\footnotetext{
35 Tradução livre do início do poema. Bibliografia: Lorenz WEINRICH, «Peter Abelard as Musician», The Musical Quarterly, vol. 55 (1969), pp. 295-312, 464-86; Peter DRONKE (com Ian BENT), «Peter Abelard: 'Planctus' and Satire», in Poetic Individuality in the Middle Ages: New Departures in Poetry 1000-1150, Oxford: Clarendon Press, 1970, pp. 114-49, 202-31; Michel HuGLO, «Abélard, poète et musicien», Cahiers de Civilisation Médiévale, vol. 22 (1979), pp. 349-61; John E. STEVENS, Words and Music in the Middle Ages: Song, Narrative, Dance, and Drama, 1050-1350, Cambridge: Cambridge University Press, 1986, pp. 119-30. Gravação discográfica: Paul HILliER, Troubadour Songs and Medieval Lyrics, Hyperion CDA66094 (1990).
} 